\title{
Subsurface Characterization Using Geoelectrical Sounding in Canaan-City Estate, Ota SW Nigeria: Implications for Groundwater Exploration
}

\author{
Kehinde D. Oyeyemi, Ahzegbobor P. Aizebeokhai, \\ and BabaMayowa A. Bayo-Solarin
}

\begin{abstract}
Well-drilling for groundwater exploration is often costly, thus it is imperative to avoid drilling dry borehole and low-yield borehole. Geoelectrical soundings were conducted in the new Canaan-City residential estate of Canaan land Ota, Ogun state. The results of VESs from the study area revealed five to six layers of five geoelectrical units which consist of the Topsoil, Sandy clay, Lateritic clay, confining bed (clay) and Main aquifer (sand). The depth to the top of the main aquifer is in the range of 40-112.4 $\mathrm{m}$. The research has further revealed that the aquifer architecture in this area is complex with undulating topography of the depth to the main aquifer. Geophysical investigations are therefore recommended in this area for groundwater exploration to be able to drill into the actual main aquifer in the area.
\end{abstract}

Keywords Subsurface characterization · Groundwater exploration · Geoelectrical sounding $\cdot$ Hydrogeophysics $\cdot$ Ota

\section{Introduction}

Groundwater exploration and management are becoming a necessity in this modern age because the inability to access groundwater as well as a constant reduction in water table makes it difficult to access this very important resource. Areas with complex geology have problems assessing groundwater, which includes the drilling of a dry borehole and drilling into low-yield aquifers in which groundwater is only available during the raining season. Thus, understanding the subsurface characteristics will help to better estimate aquifer locations; develop and manage the groundwater availability for our own gain. Groundwater investigation using geoelectrical resistivity technique is essential as it provides a clearer understanding of the subsurface geology and characteristics of the aquifer in the area [1-8]. A lot of money goes

K. D. Oyeyemi $(\varangle) \cdot$ A. P. Aizebeokhai · B. A. Bayo-Solarin

Department of Physics, Covenant University, Ota, Nigeria

e-mail: kehinde.oyeyemi@cvenantuniversity.edu.ng; kdoyeyemi@yaho.com

(C) The Editor(s) (if applicable) and The Author(s), under exclusive license

1639

to Springer Nature Switzerland AG 2021

M. Ksibi et al. (eds.), Recent Advances in Environmental Science

from the Euro-Mediterranean and Surrounding Regions (2nd Edition), Environmental

Science and Engineering, https://doi.org/10.1007/978-3-030-51210-1_260 


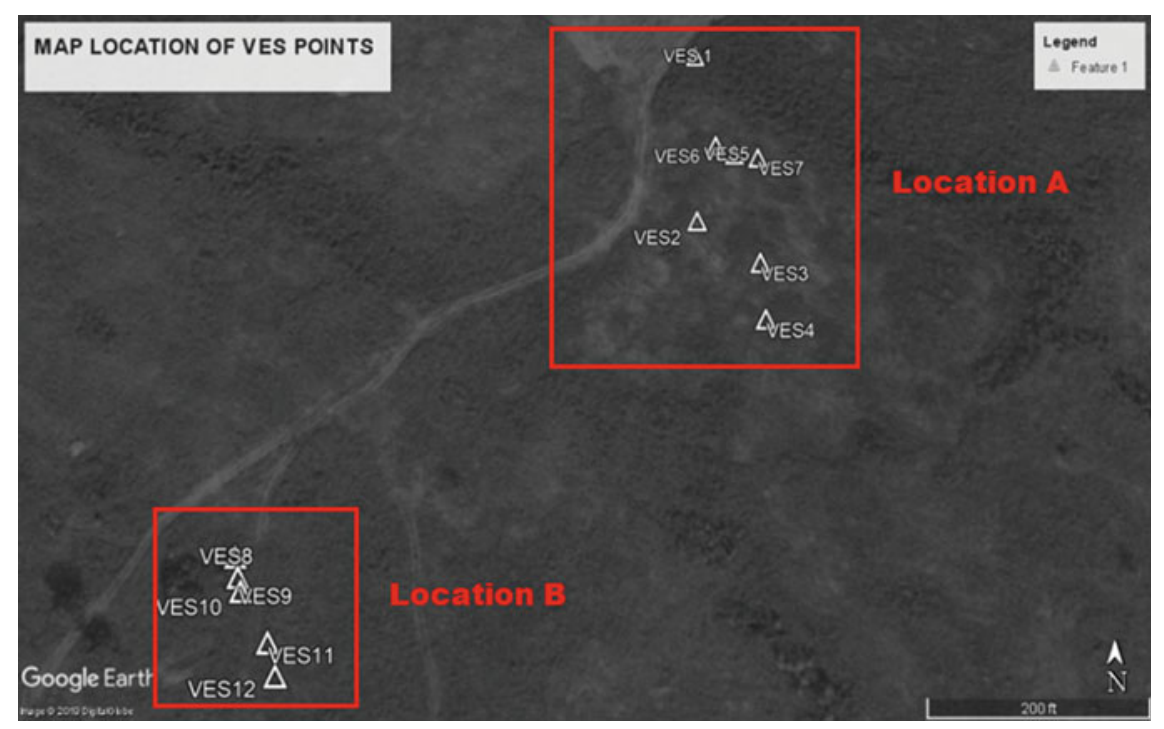

Fig. 1 Location of study area showing the VES points

into drilling of boreholes, and there is a need for a better description of the aquifer properties and even the depth-to-aquifer.

The focus of this research is to use geoelectrical resistivity method to determine the groundwater potential. It involves conducting the vertical electrical sounding (VES) essentially using the Schlumberger electrode configuration at different points within the new residential estate called Canaan-City within Ota. The understanding of the subsurface information will serve as a guide to groundwater exploration, development and management [1-8] within the estate. The selected study area for this project is Canaan-City residential estate within Ota, Ado-Odo/Ota, Ogun state, southwestern Nigeria (Fig. 1). This lies approximately within latitude $6^{\circ} 39^{\prime} 22.31^{\prime \prime}$ $\mathrm{N}$ and $6^{\circ} 39^{\prime} 32.49^{\prime \prime} \mathrm{N}$.

\section{Methods}

Vertical electrical sounding has been carried out at different points on the study area using the Schlumberger electrode configuration at 12 different points. The largest current electrode spacing $(\mathrm{AB} / 2)$ was $240 \mathrm{~m}$ on a logarithmic scale which began at $1.0 \mathrm{~m}$. The apparent resistivity of the traverses was measured using the ABEM (SAS 4000) Terrameter which was set to take the readings at a minimum of 3 cycles and a maximum of 4 cycles (i.e. it will take the mean of 3 or 4 readings). The spacing of $\mathrm{AB} / 2$ started at $1.0 \mathrm{~m}$ and increased while potential spacing $(\mathrm{MN} / 2)$ was fixed at a point until $\mathrm{AB} / 2$ became large that an increase in potential became necessary. The 
measured apparent VES resistivity data were processed using WinResist software to obtain the geoelectric layer parameters.

\section{Results and Discussion}

The interpretation of the sounding data as presented in Fig. 2 revealed five to six geoelectrical layers (Fig. 3). The first layer is the topsoil, a clay unit with inverse resistivity range of $243.5-662.9 \Omega \mathrm{m}$, with a thickness range of $1.5-2.7 \mathrm{~m}$. The second layer is interpreted to be a sandy clay unit with inverse model resistivity range of 415.3-1116.9 $\Omega \mathrm{m}$ and the thickness range of $2.2-10.5 \mathrm{~m}$. The third and fourth delineated layers are interpreted to be lateritic clay with resistivity range 171.2$1855.0 \Omega \mathrm{m}$ and thickness up to $53.9 \mathrm{~m}$. The fifth layer is the confining bed which is also a clay layer with resistivity range of $263.5-2273.8 \Omega \mathrm{m}$ and thickness range $5.7-56.8 \mathrm{~m}$. The sixth layer is interpreted to be the main aquifer unit which is a coarse sand layer, the resistivity value range $151.1-530.3 \Omega \mathrm{m}$. The depth to the top of the main aquifer within this part of the Canaan-City is averagely between 40 and $112.4 \mathrm{~m}$. They equally revealed the irregular nature of the top to the aquifer in the area and confirmed the main reason for the fact boreholes drill at different points in the area will hit the main aquifer at different subsurface depths (Fig. 3).
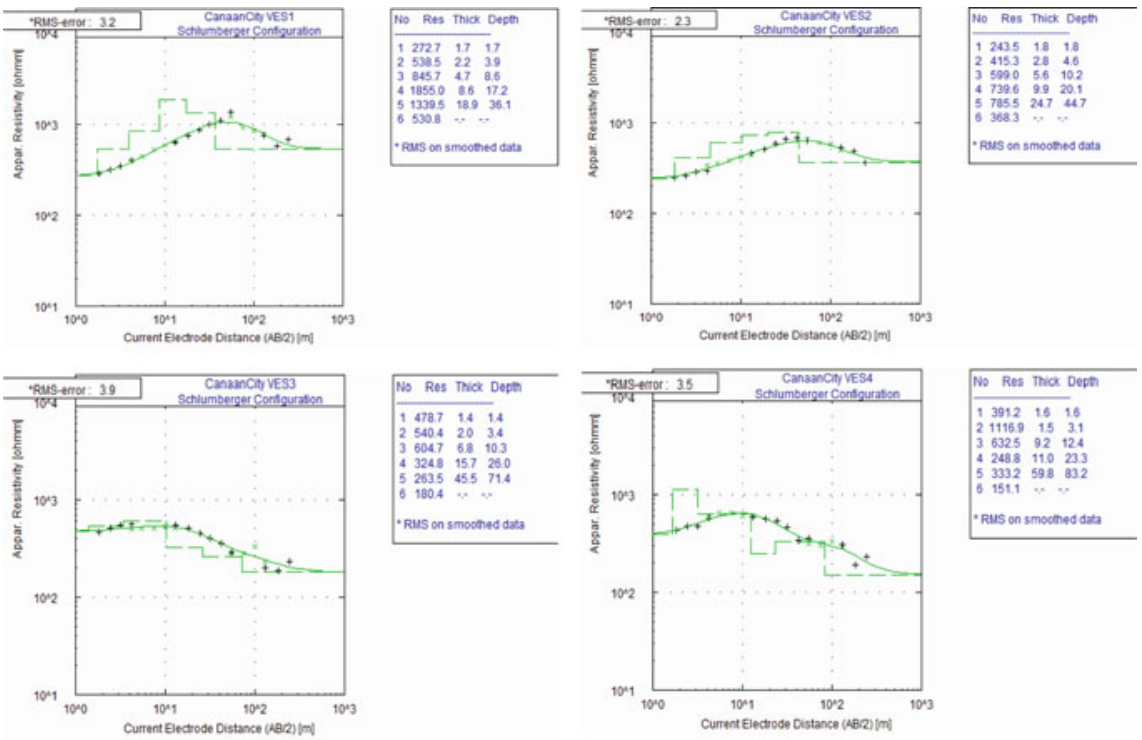

Fig. 2 Representative inverse resistivity models of VES 1-4 

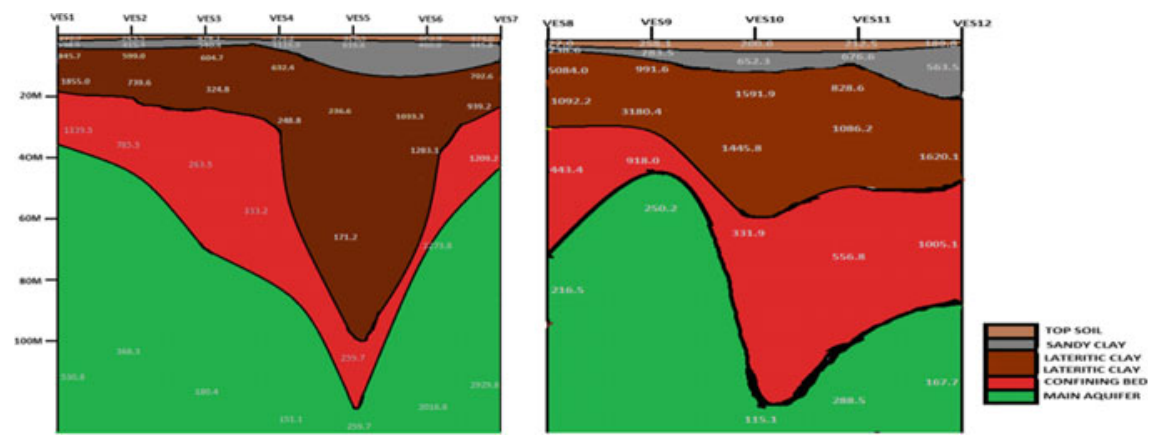

Fig. 3 Geoelectrical section through VES1-7

\section{Conclusions}

Geoelectrical soundings were conducted in the new Canaan-City residential estate of Canaan land Ota, Ogun state. The study was conducted so as to avoid drilling dry borehole and low-yield borehole in the area. The results revealed subsurface stratigraphy with geoelectrical units including the Topsoil (clay), Sandy clay, Lateritic clay, confining bed (clay) and Main aquifer (sand). The depth to the top of the main aquifer is in the range of 40-112.4 m. The delineated main aquifer architecture is generally complex with undulating topography, thus targeting this aquifer may be difficult at some points. We therefore recommend geophysical investigations prior to drilling any groundwater borehole in the study area.

\section{References}

1. Aizebeokhai, A.P., Oyeyemi, K.D.: Geoelectrical characterization of basement aquifers: the case of Iberekodo southwestern Nigeria. Hydrogeol. J. 26(2), 651-664 (2018)

2. Aizebeokhai, A.P., Ogungbade, O., Oyeyemi, K.D.: Geoelectrical resistivity dataset for characterizing crystalline basement aquifers in Basiri, Ado-Ekiti, Southwestern Nigeria. Data in Brief (Elsevier) 19, 810-816 (2018)

3. Aizebeokhai, A.P., Oni, A.A., Oyeyemi, K.D., Ogungbade, O.: Electrical resistivity imaging (ERI) data for characterising crystalline basement structures in Abeokuta, Southwestern Nigeria. Data in Brief (Elsevier) (2018). https://doi.org/10.1016/j.dib.2018.07.034

4. Oyeyemi, K.D., Aizebeokhai, A.P., Olofinnade, O.M., Sanuade, O.A.: Geoelectrical investigations for groundwater exploration in crystalline basement terrain, SW Nigeria: implications for groundwater resources sustainability. Int. J. Civil Eng. Technol. 9(6), 765-772 (2018)

5. Aizebeokhai, A.P., Oyeyemi, K.D., Joel, E.S.: Groundwater potential assessment in a sedimenatry terrain, Southwestern Nigeria. Arab. J. Geosci. (Springer) (2016). https://doi.org/10.1007/ s12517-016-2524-5

6. Aizebeokhai, A.P., Oyeyemi, K.D.: Application of geoelectrical resistivity imaging and VLFEM for subsurface characterization in a sedimentary terrain, Southwestern Nigeria. Arab. J. Geosci. (2015). https://doi.org/10.1007/s12517-014-1482-z 
7. Aizebeokhai, A.P., Oyeyemi, K.D.: Geoelectrical resistivity surveying for aquifer delineation and characterization in a sedimentary terrain, southwestern Nigeria. SEG Technical Program Expanded Abstracts, 4899-4903 (2018)

8. Aizebeokhai, A.P., Oyeyemi, K.D., Noiki, F.R., Etete, B.I. Estimation of hydrogeophysical parameters from geoelectrical resistivity sounding in Iyesi, Southwestern Nigeria. In: 80th EAGE Conference and Exhibition (2018). https://doi.org/10.3997/2214-4609.201800829 